\title{
Selection of Superior Genotypes in 37 Clones of Camu-Camu by Repetitivity Analysis
}

\author{
Mario Pinedo Panduro ${ }^{1}$, Edvan Alves Chagas ${ }^{2}$, Elvis Paredes Davila ${ }^{1}$, Carlos Abanto Rodriguez ${ }^{1}$, \\ Ricardo Bardales Lozano ${ }^{1}$, Pollyana Cardoso Chagas $^{3} \&$ Valdinar Ferreira Melo ${ }^{3}$ \\ ${ }^{1}$ Instituto de Investigaciones de la Amazonia Peruana (IIAP), Peru \\ ${ }^{2}$ Empresa Brasileira de Pesquisa Agropecuária (EMBRAPA), Brazil \\ ${ }^{3}$ Universidade Federal de Roraima (UFRR), Brazil \\ Correspondence: Mario Pinedo Panduro, Instituto de Investigaciones de la Amazonia Peruana (IIAP), Peru. \\ E-mail: mpinedo@iiap.org.pe
}

Received: March 27, 2017

Accepted: May 3, 2017 Online Published: May 15, 2017

doi:10.5539/jas.v9n6p175

URL: https://doi.org/10.5539/jas.v9n6p175

\begin{abstract}
In order to select camu-camu superior genotypes, a comparative of clones from natural populations, farmer plantations and an experimental field of the National Institute of Agrarian Innovation (INIA), was established in 2004 in varzea, at the Peruvian Amazon Research Institute (IIAP). Nine harvests between 2006 and 2016 have been evaluated, including variables in vegetative and reproductive development states. Statistical analysis was performed using the SPSS program for analysis of variance and SELEGEN REML/BLUP for repetitivity analysis of "fruit yield" (FY) and "fruit weight" (FW) with 5 and 4 measurements (years) respectively. For FY, a repetitivity index $\mathrm{r}=0.117 \pm 0.07$ was obtained with a selective precision of 0.63 and efficiency of 1.84 where clones $69,48,58$, $50,61,13,18,29,49$ and 32, were selected in descending order of merit. For FW, $r=0.690 \pm 0.294$ was obtained with selective precision of 0.948 , efficiency of 1.14 and selection of clones 44, 13, 26, 23, 69, 64 22, 52, 27 and 8 . As for the content in ascorbic acid, clones 48, 32 and 35 occupied the first places with more than $2000 \mathrm{mg}$ of ascorbic acid/100 g. The selections achieved strengthened the pre-improvement work by conferring vigour $\mathrm{y}$ fiavility of a long term research.
\end{abstract}

Keywords: amazonian fruit, ascorbic acid, genetic improvement, Myrciaria dubia

\section{Introduction}

The camu-camu (Myrciaria dubia (H.B.K) Mc Vaugh-Myrtaceae), whose center of origin is undetermined, is in a natural state in Peru, Brazil, Guyana, Colombia and Venezuela (Yuyama, 2005). Its natural habitat is wet rainforest and can be completely submerged in water for up to five months. In Peru, it is located on the banks of black water rivers of Amazonian origin, such as Nanay, Tigre, Tapiche, Yarapa, Tahuayo, Pintuyacu, Itaya, Ampiyacu, Apayacu, Maniti and numerous tributaries of the Napo, Putumayo, Yavarí and Curaray (Mendoza et al., 1989). It adapts to soils with good drainage and water regimes with droughts of up to two months.

Its facultative allogeneic reproduction generates great variability as a result of high genetic segregation. Through genetic improvement and multiplication of higher genotypes, we seek to have greater control over the traits of interest (Pinedo et al., 2004). To this end, evaluations and selections of higher plants have been carried out in each year and in some multi-year periods. The result of these selections requires validation in a more complete analysis that allows to adjust such preliminary selections.

The evaluation of the germplasm under the rigor of a "genetic test" requires the application of propagation techniques, for example, by cuttings or layers, in which the evaluation will be more precise when eliminating the variance caused by the genetic factor and the interaction rootstock/scion. The profuse rooting observed in natural populations may have stimulated numerous studies in Peru and Brazil, developed in the last 40 years to propagate the camu-camu by cuttings. This is the case of Menezes (1988) who used indolebutyric acid (AIB) achieving 73\% rooting; Pereira et al. (2002), which induced up to $80 \%$ rooting with ANA, while Galucio et al. (2002) obtained up to $90 \%$ rooting. In Peru, Oliva (2003) obtained $80 \%$ of rooting, Arévalo (2004) achieved up to $76 \%$ of rooting; Mathews (2006) also found the influence of AIB reaching averages up to $73 \%$ of rooting with sprouts; Bardales 
(2007) reached $80.4 \%$ of rooting and Mathews (2016) concluded that plants propagated by cuttings were the best because they had better base branching, which achieved significantly higher yields than seed-propagated plants.

Between 2004 and 2014, 37 camu-camu clones chosen for the present report were evaluated. According to Ramos (2010), after six years of sowing, a highly significant difference of "average fruit weight" occurred $(\mathrm{F}=2.82, \mathrm{p}<$ 0.0001). The first ten clones with the highest yield were: 17 (434.32 g/plant), 7 (373.61), 15 (335.20), 31 (227.54), 49 (219.94), 36209, 76, 64 (195.94), 53 and 50 (156.5).

After seven years of planting the 37 clones Paredes (2011), found a very significant correlation between fruit yield and mean fruit weight $(\mathrm{r}=0.33 * * \mathrm{p}=0.000)$, number of seeds $(\mathrm{R}=0.35 * * \mathrm{p}=0.000)$, ascorbic acid $(\mathrm{R}=0.23 * *$ $\mathrm{p}=0.005)$ and total basal diameter $(\mathrm{r}=0.31 * * \mathrm{p}=0.000)$. These correlations link three characters of the ideotype (Pinedo et al., 2004). According to Oliva \& Chura (2010), the parameters "number of basal branches", "petiole length" and "fruit weight" in addition to having a relatively high correlation with "fruit yield" also have an intermediate level of heritability, which catalogs them as important tools for the selection of superior plants of camu-camu.

Of these, the length of the petiole can be evaluated well in advance of fruiting and could allow the early precocious selection of high yielding plants. Second, the height of the plant could be particularly useful for selection by its early expression. Armas \& Vela (2012) chose 11 clones with higher fruit yield and their ascorbic acid content, which were chosen among the 37 clones evaluated in the present thesis. Clone 48 showed a statistically significant superiority with an average of $1938 \mathrm{mg} / 100 \mathrm{~g}$ of edible pulp. The overall average was 1486 and the order of merit at the clonal level was: $48,37,35,32,50,52,18,29,69,14,61$. With respect to the yield of the fruit in the 37 studied clones, Paredes (2013), found a wide range of 516 to $8052 \mathrm{~g} / \mathrm{pl}$ with a general average of $2718 \mathrm{~g}$; while the average fruit weight varied from 6.47 to $14.26 \mathrm{~g}$ with an average of $9.24 \mathrm{~g}$. In addition, it found a positive correlation between fruit yield and petiole length and ascorbic acid content; as well as between the average fruit weight with the number of seeds, $\%$ of pulp, $\%$ of seed, and $\%$ of peel were selected mainly for their high yields of fruits the clones: $52,49,36,14,8,37,64,50,31,48$ and 35.

The present study proposes the evaluation of 37 clones of several Loreto-Peru basins that allow the selection with repeated measures of superior genotypes according to fruit productivity, fruit weight and ascorbic acid content of the fruit

\section{Methods}

In December 2004, 37 camu-camu clones from INIA experimental fields, farmers and natural stands were installed. The field research was carried out at the Experimental Center "San Miguel" - Research Institute of the Peruvian Amazon (CESM-IIAP), located on the left bank of the Amazon River, $10 \mathrm{~km}$ from Iquitos, between coordinates $3^{\circ} 40^{\prime}$ and $3^{\circ} 45^{\prime}$ south latitude and $73^{\circ} 10^{\prime}$ and $73^{\circ} 11^{\prime}$ west longitude. The study area is flooded each year and is known as "varzea" or "restinga", with average relative humidity of $80 \%$, average temperature of $26^{\circ} \mathrm{C}$ and annual rainfall of $2911.7 \mathrm{~mm} /$ year.

From 87 pre-selected clones, 37 were selected for the experiment, taking into account: a. Number of plants available, it was considered that there should be at least 4 seedlings under suitable conditions. B. Vigor and uniformity, were included those with uniformity between the sister plants. C. Productivity, part of the clones collected were evaluated for several years regarding productivity. D. Harvest season, with atypical harvest regime, factor that was also considered in the selection of the clones to be evaluated.

The vegetative and reproductive parameters evaluated were: "petiole length", measured from the point of insertion of the petiole to the beginning of the leaf blade. Digital precision vernier was used and expressed in millimeters; "cup diameter/plant", measurements were taken with centimetric rule, the value is expressed in cm; "plant height", the measurement was made with centimetric rule of $5 \mathrm{~m}$ in length and the value is expressed in $\mathrm{cm}$; "Basal diameter of stem", measured in the neck of the plant, with the help of vernier and the value is expressed in millimeters; "number of basal branches/plant", the branches were counted at the primary level at a maximum height of $50 \mathrm{~cm}$ above the ground and whose branches were at least $2 \mathrm{~cm}$ in diameter; "number of fruits/plant", the fruits were counted in state of maximum growth (green, pinton and mature); "fruit weight", weighed 20 fruits/plant, the value was expressed in grams average, with an accuracy of one decigram; "fruit yield" was calculated by multiplying the number of fruits per plant by the average fruit weight and expressed in grams/plant. Statistical programs balanced and unbalanced were applied for the selection. Although the design of the test is balanced, it was useful to apply the basic model of the SELEGEN Program (suitable for unbalanced designs), since it allowed to calculate the precision and efficiency of the selection according to the number of measurements. 
The design of the trial is Randomized Complete Block with 37 treatments or clones with spacing of $3 \times 2 \mathrm{~m}$ and four replicates (total of 148 plants). Statistical analysis was performed using the SPSS Version 20 (2011) and Selegen-REML/BLUP models 29 and 63 (Resende, 2002). Descriptive statistical calculations (averages, ranges, variance, coefficient of variation), analysis of variance, heritability, correlation and repetitivity were performed.

In the analysis of variance the linear additive model was used:

$$
Y_{i j}=\mu+t_{i}+\beta_{j}+\epsilon_{i j}
$$

Where,

$Y_{i j}=$ Response variable corresponding to the jth observation unit, under the ith treatment;

$\mu=$ Effect of the general mean of the experiment;

$t_{i}=$ Effect of the i-th treatment;

$\beta_{j}=$ Effect of $\mathrm{j}$-th block;

$\epsilon_{i j}=$ Effect of the experimental error corresponding to the $j$-th observation, under the $i$-th treatment.

For the analysis of repetitivity that allows the selection of superior genotypes, model 63 was applied: Basic model of repetitivity:

$$
Y=X m+W p+e
$$

Where,

$Y=$ vector of the data or result obtained;

$m=$ vector of the effects of the measurement (assumed as fixed) added to the general average;

$p=$ vector of the permanent effects of the plants (genotypic effects + permanent environmental effects, assumed as random);

$e=$ vector of errors or residues (assumed as random).

The genotypic values of each plant will be estimated by:

$$
\hat{g}=M G+\beta_{p}\left(M P_{i}-M G\right) \text { in which } \beta_{p}=\frac{m \hat{\rho}}{1+(m-1) \hat{\rho}}
$$

Coefficient of determination of the permanent phenotypic value or repetitivity of the mean of:

$m=4$ measurements in the individual;

$\hat{\rho}=$ Estimate of individual repetitivity;

$M G=$ general mean of plants in various measurements;

$M P_{i}=$ general mean gives the plant $\mathrm{i}$ in the various measurements.

The genetic gain will be estimated as the average of genotypic values of the selected individuals whose components of variance (Individual REML) are:

Vfp: Permanent phenotypic variance, which is the variance of $u+a+d+e p=$ permanent phenotypic value;

Vet: Temporary environmental variance;

Vf: Individual phenotypic variance, which is the sum of additive variance + dominant variance + permanent effect variance + temporary effect variance;

A: Individual repetitivity, given by additive genetic variance + genetic variance of dominance + permanent environmental variance, all on the phenotypic variance;

Acm: Selective accuracy.

The sum of these components will be the general average.

According to Resende (2002), the classification of repetitivity is: High (greater than 0.60), Medium (between 0.30 to 0.60 ) and Low (less than 0.30 ). The same author classifies heritability in the restricted sense: low (between 0.01 to 0.015 ), medium or moderate between ( 0.15 to 0.50 ) and high (greater than 0.50 )

The results of the selection of higher plants through this analysis of repetitivity will allow to have a definitive conclusion for the choice of plants according to each one of the prioritized descriptors. This selection will allow to go to the next step of multiplication or recombination as the case may be. 


\section{Results}

Evaluations were made from 2005 to date and this report presents annual and multiannual results that involve vegetative variables on growth and development, as well as reproductive on flowering, fruiting, and ascorbic acid content. Regarding evaluations of harvests, it is important to mention that in 2013 a stand-thinning (elimination of excess plants) was carried out, leaving in the field only the most outstanding clones, which are currently still being evaluated. Therefore, according to the availability of data, the repetitivity analysis using the Selegen REML/BLUP statistical program, it was possible to apply only on five harvests $(2006,2007,2008,2009$ and 2012). However, a generic evaluation was recorded for 9 years of harvest between 2006 and 2016 (Figure 1). Below are results organized in 5 sub-titles.

\subsection{On Vegetative Variables}

In 2006, we evaluated the clones in relation with vegetative descriptors: "total basal diameter", "average basal diameter", "number of basal branches", "plant height" and "cup diameter". According to this evaluation of five descriptors the clones were selected: $29,53,44,50,42102,23,35,21,36,48,14,66,12,69$ and 52, of which the 23, 35, 66 and 69 stood out for their flower production (Table 4).

After 27 months of planting the clones, moderate values of individual heritability were found: $\mathrm{h}^{2}=0.160$ for basal diameter of the stem; $h^{2}=0.235$ for mean basal diameter; $h^{2}=0.216$ for number of basal branches; $h^{2}=0.122$ for plant height; $\mathrm{h}^{2}=0.197$ for cup diameter; $\mathrm{h}^{2}=0.169$ for number of twigs. It was deduced from four evaluations $(2005,2006,2007$ and 2008) that the best clones according to vegetative descriptors were: $14,18,29,35,44,48$, $50,52,61$ and 69 and were considered priority

In 2009, after five years of planting, the sixth evaluation of vegetative and reproductive parameters was carried out, which were consecutively evaluated at 5, 9, 23, 35, 46 and 58 months of planting. About they, a analysis of variance was applied, the summary of which is presented in Table 1.

Significant differences were found in the month 58 between clones regarding "cup diameter" $(F=10.44, p=0.00)$ and "number of flowers" $(\mathrm{F}=3.46, \mathrm{p}=0.019)$. No significant differences were found for "basal mean diameter" ( $\mathrm{F}$ $=1,773, p=0.157)$, "total basal diameter" $(F=0.368, p=0.76)$, "plant height" $(F=2.088, p=0.106)$, "number of basal branches " $(F=0.163 \mathrm{p}=0.921)$. Of the six vegetative descriptors that appear in Table 1, the ones with the greatest dispersion among the evaluated clones are "total basal diameter" and "cup diameter" and that at 23 months of planting, as evidenced by the Table, it is opportune to find wide variability in the six descriptors considered. This allows a tool for the indirect selection of desirable plants.

Table 1. Analysis of variance of vegetative variables, flowers and fruits of 37 camu-camu clones

\begin{tabular}{lllllllll}
\hline $\begin{array}{l}\text { Months since } \\
\text { planting }\end{array}$ & Plant hight & $\begin{array}{l}\text { Total basal } \\
\text { diameter }\end{array}$ & $\begin{array}{l}\text { Average basal } \\
\text { diameter }\end{array}$ & Cup diameter & $\begin{array}{l}\text { Basal branches } \\
\text { number }\end{array}$ & $\begin{array}{l}\text { Twigs } \\
\text { number }\end{array}$ & $\begin{array}{l}\text { Flowers } \\
\text { number }\end{array}$ & $\begin{array}{l}\text { Green fruits } \\
\text { number }\end{array}$ \\
\hline 5 & NS & NS & NS & & & & & \\
9 & NS & $*$ & NS & & $* *$ & $* *$ & $*$ & \\
23 & $*$ & $*$ & $* *$ & $*$ & NS & NS & NS & \\
35 & $*$ & NS & $*$ & $* *$ & $* *$ & NS & NS \\
46 & NS & $* *$ & NS & $*$ & $* *$ & NS \\
58 & NS & NS & NS & $* *$ & NS & & $*$ & NS \\
\hline
\end{tabular}

Note. NS: no significant $*$ : significant (Duncan $\mathrm{p} \leq 0.05$ ); ${ }^{* *}$ : highly significant (Duncan $\mathrm{p} \leq 0.01$ ).

\subsection{On Reproductive Variables}

After 17 months of installation, $18.8 \%$ of plants had flowers and $1.7 \%$ came to fructify. Regarding fruit yields, in the years 2, 3 and 4 of the plantation, the yields were $5.68,31.37$ and $306.00 \mathrm{~g} / \mathrm{pl}$ respectively. While in years 5 and 6 the productivity grew significantly at 1818.04 and $2691.88 \mathrm{~g} / \mathrm{pl}$. It was observed that, at 2, 3, 4, 5 and 8 years of planting, $18.24 \%, 25.00 \%, 75.00 \%, 83.78 \%$ and $99.00 \%$ of the plants started fruiting, respectively. It was deduced from four evaluations $(2005,2006,2007$ and 2008) that the best according to their yield of fruits were the clones 18, 44, 50, 61, 69, 14, 29, 35, 48 and 52 (Table 4). Clone 18 in 2008 showed fructification in the 4 replicates and $80 \%$ of the high yield clones also stood out for the vegetative descriptors.

In 2009, after five years of planting, the sixth evaluation reproductive parameters were carried out, which were consecutively evaluated at 5, 9, 23, 35, 46 and 58 months of planting. Significant differences were found between 
clones regarding "number of flowers" $(\mathrm{F}=3.46, \mathrm{p}=0.019)$. No significant differences were found for number of fruits " $(F=0.76, p=0.55)$. Significant correlations were evidenced for "basal mean diameter" versus"number of flowers" and "number of green fruits" with Pearson indices of 0.198 and 0.221 respectively. The order of merit with respect to the number of green fruits places in the first places the clones: 49, 21, 52, 32 and 53, 2/21/2004, 8 , 16,14 and 58 .

In the sixth evaluation, registered a remarkable fruiting with 11,370 fruits/plant in the plant 49-III. It is possible to mention that of these five clones, only the 53 is recidivist with respect to the previous years. These results to the fifth year of planting referred to fruiting, substantially modify the order of merits elaborated in previous years based on vegetative parameters.

In a five-year evaluation (2007-2011) the clones were selected for their persistence of high yield for 3 years: 14, 35, 44, 48, 50, 52 and 69 (Table 4). It is important to mention that in 2009 a pruning of production was carried out on the whole plot which apparently originated an irregularity in the flowering and fruiting of the clones in the years 2010 and 2011, so that the yield in 2011 was minimal.

A long-term assessment was achieved by integrating all the information collected on fruit yield during the trial. Figure 1, shows the yield trend in the 2005-2016 period. From the year 2013 the existing plants were evaluated in the plot after the stand-thinning (excess plant removal). In this work the clones of low yield were eradicated, for which they were not selected. In the $\mathrm{X}$ axis, the value 6 is missing, which corresponds to the year 2010 in which there was no harvest.

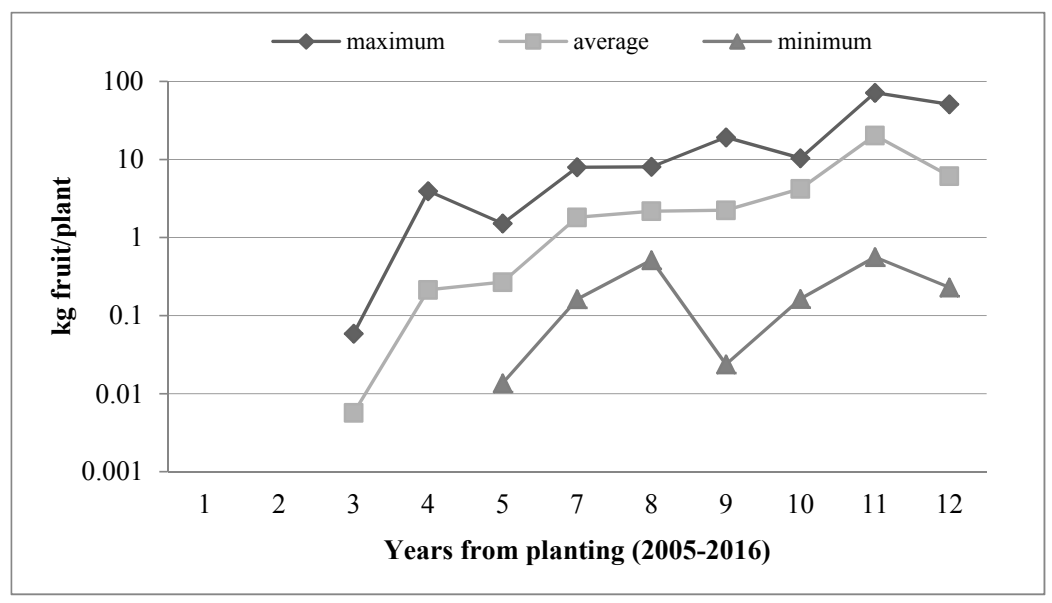

Figure 1. Yield of fruit in 37 clons of camu-camu

\subsection{Repetitivity Analysis for Yield of Five Harvests}

The analysis of variance was performed for the variable fruit yield of the 37 clones corresponding to five harvests made in the years 2006, 2007, 2008, 2009 and 2012. No differences were found between the clones ( $F=$ 1.307 sig. $=0.111)$ or between replicates or blocks $(F=1.03$ sig. $=0.379)$, while among the five measures or years of evaluation of yields a high difference was calculated $(\mathrm{F}=66.92 \mathrm{sec}=0.000)$. The means tests, corresponding to 2, 3, 4, 5 and 8 years after planting, (years 2006 to 2012), show that during the years 2,3 and 4 the yields are very similar and form part of a single relatively homogeneous group. But, from year 4 (fifth year of planting), yields begin to increase markedly. In comparative terms the average yields are very low, with an average of $2.7 \mathrm{~kg} / \mathrm{plant}$ in the eighth year.

In order to achieve greater analytical capacity given the breadth of data collected, it became necessary to apply a dynamic approach that included the values of several years in a comprehensive analysis. This study presents a multi-year repetition analysis of yield and average fruit weight, which concludes in an inclusive selection of the information achieved with the multiple annual evaluations.

The SELEGEN REML-BLUP mixed linear model 29 allowed us to analyze three factors: clones, repetitions or blocks and measurements or years, which consisted of 37 clones with four replicates and five years of harvest, having as response variable fruit yield measured in grams. The individual repetitiveness index reached a very 
low value of $r=0.027 \pm 0.017$; these results demonstrate the low genetic control over the yield of fruit, even with five measurements.

The order of merit (highest to lowest yield) for the 10 most profitable clones is as follows: $26,6,24,20,15,5,25$, 2,17 and 1. It means that if we would only use clone 26 for Installing a plantation would have a gain on the less yielding clone (the No. 8 that takes the last place) of $228.87 \mathrm{~g}$ with an average of $1199.49 \mathrm{~g}$ of fruit/plant, which means a gain of $23.58 \%$. However it would be more sustainable to use the five best clones to obtain a profit of $18.08 \%$.

Second, the repetitivity analysis was performed for repetitions or blocks, neutralizing the factor years. The basic program SELEGEN-REML/BLUP model 63 was also used, which allowed (unlike the model 29 used in the previous analysis) to obtain the efficiency level of the number of repetitions of the measurements (4 replicates in this case). The individual repetitivity index in this case was $r=0.117 \pm 0.07$ while the repetitivity of the mean of $\mathrm{m}$ crops or repeated measures was $\mathrm{rm}=0.398$. The overall mean was $998.56 \mathrm{~g} / \mathrm{plant}$.

As for the efficiency of the use of m measures (four years), a determination index of 0,346 was calculated with a selective precision of 0.588 and an efficiency of 1,721 . In order of merit, the first ten clones were: $26,6,24,17$, $20,5,25,15,2$ and 1 . If clone 26 was used for this model, the gain would be $448.47 \mathrm{~g}$ of fruit, which means a $44.91 \%$ increase in yield. If we use the five best clones, in order to increase the relative diversity of the matrices and to have a higher threshold of sustainability against the bioclimatic risks the gain in this case would be 368.43 , that is to say $36.89 \%$ of the benefit thanks to the genetics factor. Note that in this case the first five clones are not the same as in the previous calculation with model 29.

In the next analysis (Table 2), the yields evaluated over five years were prioritized and the effect of the replicates in the field was neutralized by averaging the values of the same. As in the previous case, the basic model 63 of the SELEGEN-REML-BLUP mixed linear program was applied.

In the calculation of mean components (Tables 2 and 3), a merit order of the clones according to the yield of fruit is obtained and with five years of evaluation it is the following: $26,6,24,17,20,5,25,15,2$ and 1 . The average yield is 998.5630 which appears in the last place of merit for clone 7 . The gain by applying the most yielding clone (26) is $448.46 \mathrm{~g}$ with an increased average that would reach To $1447.03 \mathrm{~g}$ which means (as in the previous analysis) a percentage gain of $44.91 \%$.

Table 2. Repetitivity analysis for five-year yield of 37 camu-camu clones (the replicates or blocks were averaged)

SELEGEN-REML/BLUP Statistical System Computerized Genetic Selection Linear Mixed Models REML-BLUP Model 63 Analyzed variable: Yield fruit with significant zeros. Standard Deviation $=2654.71$

Table 2-1. Components of variance (REML Individual)

$\mathrm{Vfp}=101697.778$ (permanent phenotypic variance between plants)

Vet $=768099.194$ (temporary environment variance, not additive)

$\mathrm{Vf}=869796.971$ (individual phenotypic variance)

$\mathrm{r}=0.117 \pm 0.07$ (individual repetitivity)

$\mathrm{rm}=0.398$ (repititivity of the mean of $\mathrm{m}$ harvests or repeated measures)

$\mathrm{Acm}=0.631$ (precision of selection based on the average of $\mathrm{m}$ harvests)

Overall average $=998,563$

Table 2-2. Efficiency of the use of m measures (5 years) for yield of fruits Selection of clones by Selegen REML-BLUP Model 63

\begin{tabular}{llll}
\hline $\mathrm{m}$ & Determination & Accuracy & Efficiency \\
\hline 1 & 0.117 & 0.342 & 1.000 \\
2 & 0.209 & 0.458 & 1.338 \\
3 & 0.284 & 0.533 & 1.559 \\
4 & 0.346 & 0.588 & 1.721 \\
5 & $\mathbf{0 . 3 9 8}$ & $\mathbf{0 . 6 3 1}$ & $\mathbf{1 . 8 4 6}$ \\
6 & 0.443 & 0.665 & 1.946 \\
7 & 0.481 & 0.693 & 2.028 \\
8 & 0.514 & 0.717 & 2.097 \\
9 & 0.544 & 0.737 & 2.156 \\
10 & 0.569 & 0.755 & 2.207 \\
\hline
\end{tabular}


Table 2-3. Components of media (BLUP Individual): Selection according to yield of fruit by basic model 63 Selegen REML-BLUP

\begin{tabular}{lllllll}
\hline Order & Individual & $\begin{array}{l}\text { Fp } \\
\text { (phenotypic value) }\end{array}$ & $\begin{array}{l}\mathrm{u}+\mathrm{fp} \\
\text { (genotypic value) }\end{array}$ & $\begin{array}{l}\text { Genetic gain } \\
(\mathrm{g})\end{array}$ & $\begin{array}{l}\text { Genetic gain } \\
(\%)\end{array}$ & $\begin{array}{l}\text { New media } \\
(\mathrm{g})\end{array}$ \\
\hline 1 & $\mathbf{6 9}$ & 448.47 & 1.447 .033 & 448.469 & 44.911 & 1.447 .033 \\
2 & $\mathbf{4 8}$ & 398.62 & 1.397 .182 & 423.544 & 42.415 & 1.422 .107 \\
3 & $\mathbf{5 8}$ & 381.81 & 1.380 .372 & 409.633 & 41.025 & 1.408 .196 \\
4 & $\mathbf{5 0}$ & 340.56 & 1.339 .127 & 392.365 & 39.292 & 1.390 .928 \\
5 & $\mathbf{6 1}$ & 272.70 & 1.271 .268 & 368.433 & 36.896 & 1.366 .996 \\
6 & $\mathbf{1 3}$ & 201.65 & 1.200 .215 & 340.636 & 34.113 & 1.339 .199 \\
7 & $\mathbf{1 8}$ & 192.66 & 1.191 .227 & 319.497 & 31.995 & 1.318 .060 \\
8 & $\mathbf{2 9}$ & 157.72 & 1.156 .286 & 299.276 & 29.970 & 1.297 .839 \\
9 & $\mathbf{4 9}$ & 123.16 & 1.121 .727 & 279.708 & 27.968 & 1.278 .271 \\
10 & $\mathbf{3 2}$ & 87.43 & 1.085 .999 & 260.480 & 26.085 & 1.259 .044 \\
33 & $\mathbf{1 4}$ & -298.83 & 699.736 & 000.000 & 00.000 & 998.563 \\
\hline
\end{tabular}

Despite the low determination rate (Table 2-2), the selection appears to be robust and reliable at the clone level with respect to fruit yield. In fact, the clones selected by the repetition test are the same ones that were highlighted in previous years (see Table 4), and make quality genetic material available for multiplication.

\subsection{Repetitivity Analysis of Fruit Weight in Four Harvests}

The individual weight of the fruit is considered a major productivity component mainly for the local market where there is preference for larger fruits, with $\geq 10 \mathrm{~g}$. This weight is considered at least in the ideotype established in the genetic improvement plan of camu-camu (Pinedo et al., 2004). For 128 plants belonging to 32 clones (included in the 37 of the present study) the average fruit weight was observed, a minimum of $4.63 \mathrm{~g}$, maximum of $14.66 \mathrm{~g}$ and average of $8.96 \mathrm{~g}$. It is considered that these values reflect genetic gain with respect to the values found in natural populations.

The analysis of variance for mean fruit weight revealed a highly significant difference between the 32 clones evaluated $(F=9.363, p=0.000)$ equally also for repetitions or blocks $(F=5.823, p=0.001)$. This test indicates the great genetic and environmental influence on the "fruit weight" character with a certain predominance of the genetic factor. The six clones selected without repetitivity analysis, having a fruit weight greater than $10 \mathrm{~g}$, were the following: 37 with $12.37 \mathrm{~g}$ from Ucayali-Requena-Plantation AMazuca, 64 with 10.76 from Putumayo-Cedro-Rodal, 50 with 10.21 from Putumayo -Molano-Rodal, 8 with 10.20 of Ucayali-Sahua-Rodal, 22 with 10.13 of Curaray-Chavarria-Rodal and 26 with 10.07 of Napo-Plantation OJipa. As we shall see later, this order of merit differs markedly from classification by the analysis of repetitivity.

The number of clones (32) and harvests (4) to be included in this repetitivity analysis was determined after a debugging of the available data. This analysis was applied with the SELEGEN-REML/BLUP Program, 2002. Mixed linear model, basic model 63.

Regarding the components of variance, it was found that the repetitivity index for fruit weight was $\mathrm{r}=$ $0.690 \pm 0.294$ (Table 3-1), which is reflected in a determination, precision and high efficiency (Table 3). 
Table 3. Repetitivity análisis for fruit weight of 32 camu-camu clones

\begin{tabular}{|c|c|c|c|}
\hline \multicolumn{4}{|c|}{ 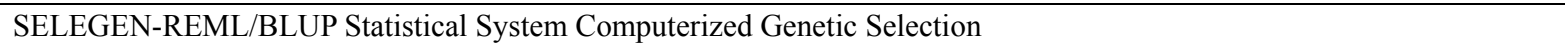 } \\
\hline \multicolumn{4}{|c|}{ Linear Mixed Model REML/BLUP Model: 63 Número de Variables: 1} \\
\hline \multicolumn{4}{|c|}{ Analyzed variable: Weight of fruit without significant zeros Standard Deviatión $=64.19$} \\
\hline \multicolumn{4}{|c|}{ Table 3-1. Components of variance (REML Individual) } \\
\hline \multicolumn{4}{|c|}{ Vfp $=1.231$ ( permanent phenotypic variance between plants) } \\
\hline \multicolumn{4}{|c|}{ Vet $=0.552$ (temporary environment variance not additive) } \\
\hline \multicolumn{4}{|c|}{$\mathrm{Vf}=1.784$ (individual phenotypic variance) } \\
\hline \multicolumn{4}{|c|}{$\mathrm{r}=0.690 \pm 0.294$ (individual repetitivity) } \\
\hline \multicolumn{4}{|c|}{$\mathrm{rm}=0.899$ (repetitivity of the mean of $\mathrm{m}$ harvests or repeated measures) } \\
\hline \multicolumn{4}{|c|}{ Acm $=0.948$ (precision of selection based on the average of $m$ harvests) } \\
\hline \multicolumn{4}{|c|}{ Overall average $=8.516$} \\
\hline \multicolumn{4}{|c|}{$\begin{array}{l}\text { Table 3-2. Efficiency of the use of } m \text { measures (4 harvests) for average fruit weight Selection of clones by SELEGEN } \\
\text { Model } 63\end{array}$} \\
\hline $\mathrm{m}$ & Determination & Accuracy & Efficiency \\
\hline 1 & 0.690 & 0.831 & 1.000 \\
\hline 2 & 0.817 & 0.904 & 1.088 \\
\hline 3 & 0.869 & 0.933 & 1.122 \\
\hline 4 & 0.899 & 0.948 & 1.141 \\
\hline 5 & 0.918 & 0.958 & 1.153 \\
\hline 6 & 0.930 & 0.964 & 1.161 \\
\hline 7 & 0.939 & 0.969 & 1.168 \\
\hline 8 & 0.947 & 0.973 & 1.171 \\
\hline 9 & 0.953 & 0.976 & 1.175 \\
\hline 10 & 0.957 & 0.978 & 1.177 \\
\hline
\end{tabular}

Tabla 3-3. Components of media (BLUP Individual) Selection according to weight of fuit by basic model 63 Selegen-REML-BLUP

\begin{tabular}{lllllll}
\hline Order & Individual & $\begin{array}{l}\mathrm{fp} \\
\text { (fenotipic value) }\end{array}$ & $\begin{array}{l}\mathrm{u}+\mathrm{fp} \\
(\text { genotipic value) }\end{array}$ & $\begin{array}{l}\text { Genetic gain } \\
(\mathrm{g})\end{array}$ & $\begin{array}{l}\text { Genetic gain } \\
(\%)\end{array}$ & $\begin{array}{l}\text { New media } \\
(\mathrm{g})\end{array}$ \\
\hline 1 & $\mathbf{4 4}$ & 1.525 & 10.041 & 1.525 & 17.907 & 10.041 \\
2 & $\mathbf{1 3}$ & 1.066 & 9.583 & 1.296 & 15.218 & 9.812 \\
3 & $\mathbf{2 6}$ & 0.738 & 9.255 & 1.110 & 13.034 & 9.626 \\
4 & $\mathbf{2 3}$ & 0.711 & 9.228 & 1.010 & 11.860 & 9.527 \\
5 & $\mathbf{6 9}$ & 0.426 & 8.942 & 0.893 & 10.486 & 9.410 \\
6 & $\mathbf{6 4}$ & 0.415 & 8.931 & 0.814 & 9.558 & 9.330 \\
7 & $\mathbf{2 2}$ & 0.365 & 8.882 & 0.749 & 8.795 & 9.266 \\
8 & $\mathbf{5 2}$ & 0.343 & 8.860 & 0.699 & 8.208 & 9.215 \\
9 & $\mathbf{2 7}$ & 0.167 & 8.684 & 0.639 & 7.503 & 9.156 \\
10 & $\mathbf{8}$ & 0.109 & 8.625 & 0.587 & 6.893 & 9.103 \\
16 & $\mathbf{1 4}$ & -3.060 & 5.455 & 0.000 & 0.000 & 8.516 \\
\hline
\end{tabular}




\subsection{Integral Results for Selection}

Table 4. Selections comparison of camu-camu's clones by test of medias and repetitivity analyze for yield and fruit weight

\begin{tabular}{|c|c|c|c|c|c|c|}
\hline \multirow{3}{*}{ Order of Merit } & \multicolumn{4}{|c|}{ Merit according to the weight of fruit } & \multirow{2}{*}{\multicolumn{2}{|c|}{$\begin{array}{l}\text { Repetitivity (REML-BLUP) } \\
\text { for yield of fruit }\end{array}$}} \\
\hline & \multicolumn{2}{|c|}{ Repetitivity REML-BLUP } & \multicolumn{2}{|c|}{ Media Duncan } & & \\
\hline & Clon & New media & Clon & Media & Yield & New media \\
\hline 1 & 44 & 10.04 & 37 & 12.37 & 69 & 1447.03 \\
\hline 2 & 13 & 9.81 & 64 & 10.76 & 48 & 1422.11 \\
\hline 3 & 26 & 9.62 & 50 & 10.21 & 58 & 1408.18 \\
\hline 4 & 23 & 9.52 & 8 & 10.20 & 50 & 1390.93 \\
\hline 5 & 69 & 9.41 & 3 & 10.13 & 61 & 1366.99 \\
\hline 6 & 64 & 9.33 & 26 & 10.07 & 13 & 1339.19 \\
\hline 7 & 22 & 9.26 & 27 & 9.83 & 18 & 1318.06 \\
\hline 8 & 52 & 9.21 & 15 & 9.73 & 29 & 1297.84 \\
\hline 9 & 27 & 9.16 & 48 & 9.70 & 49 & 1278.27 \\
\hline 10 & 8 & 9.10 & 52 & 9.59 & 32 & 1259.04 \\
\hline 11 & $02 / 21 / 08$ & 9.03 & 12 & 9.33 & 16 & 1241.37 \\
\hline 12 & 37 & 8.96 & 31 & 9.30 & 53 & 1223.12 \\
\hline 13 & $14 / 21 / 07$ & 8.89 & 35 & 8.99 & 44 & 1207.01 \\
\hline 14 & 15 & 8.80 & 53 & 8.97 & 8 & 1191.71 \\
\hline 15 & 32 & 8.72 & 17 & 8.92 & 23 & 1175.58 \\
\hline
\end{tabular}

Table 5 summarizes the merit order of the top 15 selected clones by average fruit weight and yield. In column 1 are the selected clones because fruit of greater weight according to the analysis of repetitiveness applied. Clone 44 occupies the first place with a capacity to achieve in the clonal population $10.04 \mathrm{~g}$. In column 3 is the group of clones selected according to the fruit weight averages, where clone 37 occupies the first place with $12.37 \mathrm{~g}$. However, in the group selected by repetitive analysis, it occupies the number 12 site. This large difference results from the correlation found by analysis of repetitivity in a series of five years, whereas in the test of medias, the values not considere the degree of correlation between years. Regarding the provenance of the selected clones, stands predominate the natural populations (without management or domestication), since for both yield and fruit weight $60 \%$ of the selected plants come from natural lakes, mainly Of the rivers Putumayo and Curaray. Note that two clones, 69 and 13 are in the two groups (yield and fruit weight).

Table 5. Selections of the better ten clones of camu-camu on period 2005-2013

\begin{tabular}{|c|c|c|c|c|c|c|c|c|c|c|c|c|c|c|c|c|}
\hline \multicolumn{2}{|c|}{ Descriptor } & \multicolumn{2}{|c|}{ Vegetatives } & \multicolumn{4}{|c|}{ Wheight of fruit } & \multicolumn{7}{|c|}{ Yield of fruit } & \multicolumn{2}{|c|}{ Ascorbic Acid } \\
\hline Method & Duncan & Manual & Manual & Duncan & Manual & SELEGEN & Kruskal & Manual & Manual & Duncan & Manual & Manual & SELEGEN & Tukey & Duncan & Kruskal \\
\hline Author & Pinedo & Pinedo & Pinedo & Ramos & Paredes & Pinedo & Paredes & Pinedo & Pinedo & Ramos & Paredes & Paredes & Pinedo & Paredes & Armas & Paredes \\
\hline Year & 2005 & 2006 & $\begin{array}{l}2005 / \\
2008\end{array}$ & 2010 & 2011 & $\begin{array}{l}2005 / \\
2012\end{array}$ & 2013 & $2005 / 2008$ & 2009 & 2010 & $\begin{array}{l}2007 / \\
2009\end{array}$ & $\begin{array}{l}2006 / \\
2010\end{array}$ & $\begin{array}{l}2005 / \\
2012\end{array}$ & 2013 & $2012(*)$ & $2013(*)$ \\
\hline Merit & & & & & & & & Clones & & & & & & & & \\
\hline 1 & 53 & 29 & 14 & 64 & 37 & 44 & 64 & 18 & 49 & 17 & 14 & 52 & 69 & 52 & 48 & 48 \\
\hline 2 & 8 & 53 & 18 & 15 & 64 & 13 & 37 & 44 & 21 & 7 & 35 & 49 & 48 & 36 & 37 & 37 \\
\hline 3 & 44 & 44 & 29 & 36 & 50 & 26 & 8 & 50 & 52 & 15 & 44 & 36 & 58 & 14 & 35 & 35 \\
\hline 4 & 50 & 50 & 35 & 53 & 8 & 23 & 50 & 61 & 32 & 31 & 48 & 14 & 50 & 49 & 32 & 64 \\
\hline 5 & 48 & 42102 & 44 & 66 & 3 & 69 & 15 & 69 & 53 & 49 & 50 & 8 & 61 & 8 & 50 & 52 \\
\hline 6 & 29 & 23 & 48 & 52 & 26 & 64 & 31 & 14 & 22104 & 36 & 52 & 37 & 13 & 29 & 52 & 50 \\
\hline 7 & 18 & 35 & 50 & 61 & 27 & 22 & 52 & 29 & 8 & 64 & 69 & 64 & 18 & 37 & 18 & 32 \\
\hline 8 & 55 & 21 & 52 & 18 & 15 & 52 & 58 & 35 & 16 & 53 & 18 & 50 & 29 & 66 & 29 & 53 \\
\hline 9 & 16 & 36 & 61 & 49 & 48 & 27 & 27 & 48 & 14 & 50 & 29 & 31 & 49 & 50 & 69 & 23 \\
\hline 10 & 69 & 48 & 69 & 8 & 52 & 8 & 13 & 52 & 58 & 22104 & 53 & 48 & 32 & 61 & 14 & 18 \\
\hline
\end{tabular}

$(*)$ The two selections correspond to the same database analyzed in 2012, the difference is only of the type of means tests. 
Table 5 shows 16 selections made according to vegetative morphological markers, fruit weight, fruit yield and ascorbic acid. As for vegetative variables, the "average basal diameter" evaluated at 9 months after planting, was the selection criteria in 2005 . It was found that $90 \%$ of the clones that were selected according to this marker, all except clone 55 are also reported as superior according to the repetitivity analyzes for fruit yield in subsequent years. The heritability index for mean basal diameter in the broad sense $\left(\mathrm{h}^{2} \mathrm{~g}\right)$ was $0.236 \pm 0.113$ considered medium to moderate by Resende (2002). This value was higher than the other vegetative markers evaluated: total basal diameter, number of basal branches, plant height and crown diameter. For the selection by vegetative descriptors carried out in the year 2006 the four pre-cited descriptors were taken into account. As a result we obtained a $50 \%$ different selection from that of 2005 but $80 \%$ of the selected clones are among the lists of high yield fruit clones. In 2008 ( 4 years from the plantation) a comprehensive evaluation was made of the previous 4 years including 2008, selecting the best plants. This selection was based on vegetative variables: total basal diameter, mean basal diameter, number of basal branches, plant height, crown diameter, and number of tips (terminal twigs). $100 \%$ of the selected clones are also high yield of fruits. Four selections of clones with large fruit are shown in Table 4, where some of them stand out because they have been selected in the four opportunities. Seven selections for fruit yields performed using repetition analysis, parametric (Tukey and Duncan) and non-parametric (Kruskal and Walis) tests as well as direct quantitative comparison (indicated in Table 5 as manual). The analysis with SELEGEN corresponding to five harvests made in the period between 2005-2012 is the most integral for the purposes of a selection of greater robustness. At the right end of Table No. 4 are two selections according to the content of ascorbic acid; It should be reiterated that both selections come from a single group of analysis and the difference is the statistical program applied, SPSS and Kruskal and Walis. It is observed a coincidence of the clones 48,37 and 35 that occupy the first places.

\section{Discussion}

Among the vegetative variables evaluated, the "basal diameter of the stem" was highlighted due to its higher level of heritability and correlation with fruit yield. When comparing basal diameter selections made at 9 months of planting versus selection for fruit yield between 2005 and 2013 (Table 4), a 90\% correspondence was found. Such relationship evidences the predictive capacity of the variable "basal diameter of the stem" to indirectly select genotypes with high yield. Bardales et al. (2016), demonstrated the utility of vegetative descriptors even in very early stage as seedling height, germination percentage and speed suchas best indicators of genetic diversity in natural populations of camu camu in the state of Roraima, Brazil. Also, Almeida et al. (2016) used the vegetative variables "basal trunk diameter" $(\mathrm{mm})$, "plant height" $(\mathrm{cm})$, "number of basal shoots" and "number of terminal shoots" para seleccionar UAT 1896-7, UAT 1596-7 and UAT 1096-5 subsamples with the largest number of terminal shoots and height. Subsample UAT 0796-8 showed a good amount of terminal shoots, but inferior initial height, with interesting dwarf characteristics.

It was observed that the fruiting in the present study, started with relative delay and with very low yields ( $25 \%$ of the plants in production at 3 years with $52.28 \mathrm{~kg} / \mathrm{ha}$ ). This relative delay in starting the harvest differs from that found by Pinedo et al. (2001), which shows that at 3 years this parameter reaches $51.9 \%$. Likewise, Mathews (2016) in highland and with fertilization reached $80 \%$ of fruiting at 30 months with yield of $204 \mathrm{~kg} / \mathrm{ha}$.

Although at the population level the delay in the camu-camu harvest was observed at the individual level, very early production was recorded. Thus, Almeida et al. (2016) reports that two individuals (UAT 1896-7 and UAT 1796-7) presented the onset of fruit production at 18 months, which is similar to what was found in this study in that after 17 months of Installation $18.8 \%$ of the plants had flowers and $1.7 \%$ began to fructify.

Aguirre et al. (2011), evaluated the fruit yield of 4 camu-camu clones in Pucallpa, finding a maximum of $8.44 \mathrm{t}$ of fruit/ha in 2010 ( 7 years of age). In the present study yields reached $2.25 \mathrm{t}$ of fruit/ha at 8 years. However, these yields are similar to those found by INIA in the best genotypes: MD-13, MD-14, MD-15, MD-17, MD-20 at 15 years of planting. These results were shown by Pinedo et al. (2010) who found a general average of 130.6 fruits/plant, explaining that in the 5 promising genotypes of camu-camu there are productions greater than 2000 $\mathrm{kg} / \mathrm{ha}$ of fruit.

As for the repetitiveness analysis, it was observed that the determination index $r$ for fruit yield in the first year is quite low, which increases significantly, allowing a genetic control of intermediate level to the fifth year of harvest (Table 1). However, Oliva and Resende (2006), when evaluating 315 camu-camu plants, found greater genetic control with a repetitivity $\mathrm{r}=0.77$ for the average of five harvests favoring a selective accuracy of 0.88 . Oliva and Chura (2010), evaluated 77 introductions of camu-camu and found values similar to those of the present study with repetitibity index for 4 harvests of $r=0.49$. 
It is frequent to find, high influence of the environmental variance on characteristics of fruit production, mainly of quantitative inheritance. In this sense, Degenhardt et al. (2002), with three years of evaluation, determined that a minimum of six harvests would be necessary for the selection of high yielding guava-serrana (Acca sellowiana) genotypes with $80 \%$ accuracy.

On fruit yield the levels of repeatitivity were relatively low in the present assay with camu-camu clones. Asexual propagation, it was assumed that genetic control could be of a higher level with respect to sexually propagated material. This was verified in the case of copoazu (Theobroma grandiflorum) by Alves and Resende (2008) who verified a much higher genetic gain through clonal propagation compared to sexual propagation. It should be noted that the agronomic management was minimal in the plot under study and that it is a floodable area.

We observed that the average fruit weight $(8.51 \mathrm{~g})$ obtained in the present test is considerably high, attributable to the bias toward large fruit when the cuttings were collected. Oliva (2002) found an average of $8.17 \mathrm{~g}$ in plantations and natural stands of Loreto. While in the basic collection from five basins of Loreto-Peru, Guillen and Pinedo (2007), they found an average of $7.13 \mathrm{~g}$ with a range of 4.69-10.62 g; The most basic condition of selection of this material explains the values of average and lower range.

The individual repetitivity coefficient $(r=0.6903)$ expressed for fruit weight in Table 2-3 shows, unlike fruit yield, an important genetic control for this character with only one evaluation crop. In the fourth harvest, applied in the analysis said index increased to $r=0.8991$, with an accuracy of 0.9482 and efficiency of 1.1412 . This efficiency would be achieved through the use of clone 44 that occupies the first place, an average weight of $10.04 \mathrm{~g}$ reaching what was proposed in the ideotype of the genetic improvement plan of camu-camu (Pinedo et al., 2004)

In the simple (non-repetitivity) analysis of fruit weight of the 32 clones, clone 37 took the first place with an average of $12.37 \mathrm{~g}$ from a Ucayali-Requena river plantation owned by Mr. Alfredo Mazuca. At the time of harvest, it is classified as a plant bearing small fruits. Apparently in the rametes resulting from propagation by stakes has been given greater genetic expression probably favored by the environment (climatic and edaphic factors); Which allowed to reach the highest average forming a significantly higher monoclonal group. However in the repetitivity analysis clone 37 was relegated to the 12th place in the order of merit by not showing a consistent correlation between the four measurements and was exceeded by 11 clones.

High genetic control of productivity variables were also found in other tropical fruits such as mango (Mangifera indica L.), on which Gomes (2003), applied the principal components method. We estimated several coefficients of repetitivity with values of $0.51,0.53$ and 0.81 for "total number of fruits per plant", "yield of fruits per plant" and "average weight of fruits", respectively. These estimates were associated with coefficients of determination (r2) of $80.44 \%, 81.60 \%$ and $94.41 \%$. The reference to "average fruit weight" showed high regularity in the superiority of individuals from one cycle to another, with only three crops being necessary to predict values with a certainty level above 90\%. Alves and Resende (2008) in Para-Brazil, for four harvests of Copoazu (Theobroma grandiflorum) found for individual fruit number repetitions ( $\mathrm{r}$ ) of $35 \%$. The individual heritability of the number of fruits in 4 harvests, increased to $48 \%$, favoring a selective precision of $70 \%$. Similarly, Nascimento et al. (2014) found that "fruit weight" and "bark weight" accounted for $54.09 \%$ of the variation among progenies, verifying that the causes are more genetic than environmental. The "fruit weight" also stands out for its high heritability (0.96), desirable for an improvement program.

\section{Conclusions}

Using multiyear repetitivity analysis (SELEGEN REML-BLUP) from five harvests of 37 clones of camu-camu, they were selected for fruit yield in the first ten places the clones $69,48,58,50,61,13,18,29,49$ and 32. According to the average fruit weight, clones 44, 13, 26, 23, 69, 64, 22, 52, 27 and 8 were selected. While clones 48, 32 and 35, they ranked first according to the acid ascorbic content. According to the repetitivity indices, the average fruit weight presents a notoriously greater genetic control than fruit yield. The method applied for the multi-year selection allows to complement the previous selections made with other methods and to conclude in a list of plants with greater reliability and support.

\section{Acknowledgements}

We express our gratitude to CAPES and CNP for the scholarship granted to the first author of the research and $\mathrm{CNPq}$ for the productivity grant to researcher Edvan Chagas. Also to the IIAP and Dennis Del Castillo for supporting the development of research on camu-camu and the author's doctoral training. 


\section{References}

Aguirre, O., Abanto, C., Oliva, C., Zumaeta, D., \& Chia, S. (2011). Evaluación agronómica de cuatro clones de camu-camu [Myrciaria dubia (H.B.K) Mc Vaugh] en un suelo aluvial inundable de la región Ucayali. Investigación y Amazonía, 1(2), 70-77.

Almeida, L. F. P., Yuyama, K., Chagas, E. A., Lozano, R. M. B., Albuquerque, T. C. S., Abanto, C. R., \& Queiroz, F. B. (2014). Early Evaluation of Camu-Camu Subsamples in Transition Savanna/Forest Area. Journal of Agricultural Science, 6(11), 178-186. https://doi.org/10.5539/jas.v6n11p178

Alves, M., \& Resende, V. (2008). Avaliação genética de indivíduos e progênies de cupuacuzeiro no estado do Para e estimativas de parâmetros genéticos. Revista Brasileira de Fruticultura, 30(3), 696-701. https://doi.org/10.1590/S0100-29452008000300023

Arévalo, L. (2004). Efecto del sistema de riego, posición y diámetro de la estaca, en el enraizamiento del camu-camu (Myrciaria dubia H.B.K. McVaugh) (p. 125, Tesis pre-grado no publicada). Facultad de Agronomía. Universidad Nacional de la Amazonia Peruana. Retrieved from http://repositorio.unapiquitos. edu.pe/handle/UNAP/1880

Armas, M., \& Vela, T. (2012). Concentración de ácido ascórbico en frutos de Myrciaria dubia (H.B.K.) McVaugh del banco de germoplasma del Centro Experimental San Miguel (p. 30, Tesis Pre-Grado no publicada). Universidad Nacional de la Amazonia Peruana, Instituto de Investigaciones de la Amazonia Peruana, Tesis Químico Farmacéutico.

Bardales, R., Pérez, M., \& Pinedo, M. (2007). Tres concentraciones de ácido indolbutírico en tres diámetros de estaca y su efecto en la tasa de propagación vegetativa del camu-camu Myrciaria dubia (H.B.K.) Mc Vaugh. (Tesis pre-grado no publicada). Universidad Nacional de la Amazonia Peruana. Retrieved from http://www.iiap.org.pe/Upload/Avance/bosque6.pdf

Bardales-Lozano, R. M., Alves, Ch. E., Smiderle, O., Abanto-Rodriguez, C., Cardoso, Ch. P., Barbosa, M. A., ... Centeno, C. A. C. (2016). Genetic divergence among camu-camu plant populations based on the initial characteristics of the plants. Journal of Agricultural Science, 8(11), 51-58. https://doi.org/10.5539/ jas.v8n11p51

Degenhardt, J., Ducroquet, J., Sedrez, R., Guerra, P., \& Nodari, O. (2002). Efeito de anos e determinação do coeficiente de repetitividade de características de frutos de goiabeira-serrana(1). Pesquisa Agropecuaria, 37(9), 1285-1293. https://doi.org/10.1590/S0100-204X2002000900012

Galucio, B., \& Yuyama, K. (2002). Produção de Mudas de camu-camu (Myrciaria dubia. H. B. K. Mc Vaugh), por estaquia utilizando ramos provenientes de diferentes tipos de posições de planta. Monografia Presentada: Universidad do Amazonas (UA).

Gomes, J. (2003). Estimativas de repetitividade de alguns caracteres de produção em Mangueira. Ciência Rural, 33(2), 263-266. https://doi.org/10.1590/S0103-84782003000200013

Guillen, I. (2007). Evaluación y mantenimiento de germoplasma de camu-camu colectado en poblaciones naturales (p. 50, Tesis pre-grado no publicada). Universidad Nacional de la Amazonia Peruana, Instituto de Investigaciones de la Amazonia Peruana.

Mathews, J. (2006). Efectos del ácido indolbutirico y el tamaño de estaca, en el enraizamiento y brotación del camu camu (Myrciaria dubia Mc Vaugh) (Tesis pre-grado no publicada). Universidad Nacional de la Amazonia Peruana, Facultad de Agronomía, Iquitos, Perú.

Mathews, J., Yuyama, K., \& Revilla, J. (2016). Does a greater number of branches improve initial fruit production in camu-camu? A test under different types of plantations and cropping management. Fruits, 71(1), 1-7. https://doi.org/10.1051/fruits/2015045

Mendoza, O., Picón, C., Gonzales, J., Cárdenas, R., Padilla, C., \& Mediavilla, M. (1989). Informe de la expedición de recolección de germoplasma de Camu-camu (Myrciaria dubia) en la Amazonia Peruana ( $\mathrm{p}$. 19). Instituto Nacional de Investigación Agraria y Agroindustrial, Lima, Perú.

Menezes, D. (1988). Efeitos de diferentes reguladores de crescimento sobre o enraizamento de estacas de camu-camu (Myrciaria dubia (H.B.K.) Mc Vaugh) (p. 2). FCA/UA. Brasil.

Nascimento, W. M. O. do, Gurgel, F., Bhering, L. L., \& Ribeiro, O. D. (2014). Pre-breeding of camucamuzeiro: A study of genetic parameters and dissimilarity. Rev. Ceres., 61(4), 538-543. https://doi.org/10.1590/ 0034-737X201461040013 
Oliva, C. (2002). Evaluación de la productividad del camu-camu (Myrciaria dubia H.B.K. McVaugh) en Loreto (p. 102, Tesis pre-grado no publicada). Universidad nacional de la Amazonia Peruana, Facultad de agronomía.

Oliva, C. (2003). Efecto de hormonas enraizantes y la temperatura en el enraizamiento de estacas de camu-camu arbustivo (Myrciaria dubia H.B.K.McVaugh) en Ucayali-Perú. Informe tecnico-IIAP-Ucayali.

Oliva, C., \& Chura, J. (2010). Selección genética computarizada, a partir del banco de germoplasma Myrciaria dubia (H.B.K.) camu-camu arbustivo McVaugh, de la EE-San Roque-INIA Loreto, Perú. Universidad Nacional Agraria de la Molina. Escuela de Post Grado "Mejoramiento Genético de Plantas".

Oliva, C., \& Resende, V. (2008). Mejoramiento genético y taza de autofecundación del camu-camu arbustivo en la amazonía peruana. Rev. Bras. Frutic., 30(2), 450-454. https://doi.org/10.1590/S0100-29452008000200031

Paredes, E. (2013). Comparativo de 37 clones de camu-camu arbustivo (Myrciaria dubia-Myrtaceae)-séptimo año de la plantación (p. 9). Universidad Nacional de la Amazonia Peruana. Instituto de Investigaciones de la Amazonia Peruana. Retrieved from http://repositorio.unapiquitos.edu.pe/handle/UNAP/18173

Pereira, B., \& Yuyama, K. (2002). Producto de mudas de camu-camu (Myrciaria dubia-H.B.K.Mc Vaugh) por estaquia utilizando ramos provenientes de diferentes tipos e posicoes da planta (p. 6). INPA.

Pinedo, M. (2006). Comparativo de clones de camu-camu (Myrciaria dubia-Myrtaceae) en San Miguel (p. 32). Informe de avance al segundo año del establecimiento, Instituto de Investigaciones de la Amazonia Peruana.

Pinedo, M. (2009) Evaluación de germoplasma y pruebas genéticas de material promisorio al 7 mo año del establecimiento (p. 113). Informe Técnico, Instituto de Investigaciones de la Amazonia Peruana.

Pinedo, M. (2013). Correlation and heritability analysis in breeding of camu-camu [Myrciaria dubia (Kunth) McVaugh]. Peruvian Amazon Research Institute, Iquitos, Peru (IIAP). African Journal of Plant Science, 7(2), 61-66. https://doi.org/10.5897/AJPS12.023

Pinedo, M., \& Paredes, E. (2011). Evaluación preliminar de 108 progenies precoces de camu-camu Myrciaria dubia (Myrtaceae) en Loreto, Perú. Instituto de Investigaciones de la Amazonia Peruana. Folia Amazónica, 20(1-2), 77-82.

Pinedo, M., \& Ramos, J. (2008). Comparativo de clones de camu-camu en San Miguel; Cuarto año de evaluación (p. 15). Informe Técnico. Instituto de Investigaciones de la Amazonia Peruana, Programa de Ecosistemas Terrestres, Loreto, Perú.

Pinedo, M., Linares, C., Mendoza, H., \& Anguiz, R. (2004). Plan de Mejoramiento Genético de camu-camu (p. 52). Instituto de Investigaciones de la Amazonia Peruana, Programa de Ecosistemas Terrestres, Loreto, Perú. Retrieved from http://www.iiap.org.pe

Pinedo, M., Riva, R., Rengifo, E., Delgado, C., Villacres, J., \& Gonzales, J. (2001). Sistema de producción de camu-camu en resting (p. 141, 634.6 S623). Instituto de Investigaciones de la Amazonia Peruana, Iquitos, Perú.

Pinedo, P., Delgado, C., Farroñay, M., Del Castillo, D., Villacrez, J., \& Faching, L. (2010). Camu-camu (Myrciaria dubia-Myrtaceae); aportes para su aprovechamiento sostenible en la Amazonia Peruana (p. 135). Instituto de Investigaciones de la Amazonia Peruana, PROBOSQUES.

Ramos, J. (2010). Comparativo de 37 clones de camu-camu arbustivo Myrciaria dubia (H.B.K) Mc Vaugh en Loreto (p. 143, Tesis Pre-Grado no publicada). Universidad Nacional de la Amazonia Peruana. Retrieved from http://repositorio.unapiquitos.edu.pe/handle/UNAP/1816

Resende, M. (2002). Genetica biométrica e estatistica no melhoramento de plantas perenes (p. 975). Brasilia: Embrapa Informacao Tecnologica.

\section{Copyrights}

Copyright for this article is retained by the author(s), with first publication rights granted to the journal.

This is an open-access article distributed under the terms and conditions of the Creative Commons Attribution license (http://creativecommons.org/licenses/by/4.0/). 